\title{
Graft-Versus-Tumor Induction
}

National Cancer Institute

\section{Source}

National Cancer Institute. Graft-Versus-Tumor Induction. NCI Thesaurus. Code C8302.

An immune response that involves a reaction by immune cells that are present in transplanted tissue, such as bone marrow or peripheral blood, to a recipient's tumor cells.

The introduction or transplantation of immune-sensitive moieties to a host are being evaluated in several clinical trials as a primary therapy for patients with malignancies. 